\title{
Fault Analysis at a Wind Power Plant for One Year of Observation
}

Conference Paper NREL/CP-500-42885 July 2008

\section{Preprint}

E. Muljadi

National Renewable Energy Laboratory

Z. Mills and R. Foster

New Mexico State University

J. Conto

ERCOT

A. Ellis

Public Service Company of New Mexico

To be presented at the 2008 IEEE Power Engineering Society General Meeting

Pittsburgh, Pennsylvania

July 20-24, 2008

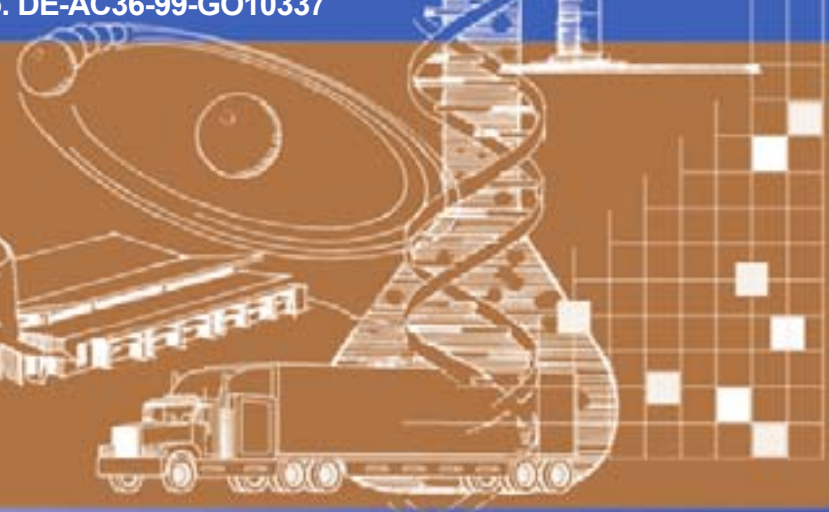




\section{NOTICE}

The submitted manuscript has been offered by an employee of the Midwest Research Institute (MRI), a contractor of the US Government under Contract No. DE-AC36-99G010337. Accordingly, the US Government and MRI retain a nonexclusive royalty-free license to publish or reproduce the published form of this contribution, or allow others to do so, for US Government purposes.

This report was prepared as an account of work sponsored by an agency of the United States government. Neither the United States government nor any agency thereof, nor any of their employees, makes any warranty, express or implied, or assumes any legal liability or responsibility for the accuracy, completeness, or usefulness of any information, apparatus, product, or process disclosed, or represents that its use would not infringe privately owned rights. Reference herein to any specific commercial product, process, or service by trade name, trademark, manufacturer, or otherwise does not necessarily constitute or imply its endorsement, recommendation, or favoring by the United States government or any agency thereof. The views and opinions of authors expressed herein do not necessarily state or reflect those of the United States government or any agency thereof.

Available electronically at http://www.osti.gov/bridge

Available for a processing fee to U.S. Department of Energy and its contractors, in paper, from:

U.S. Department of Energy

Office of Scientific and Technical Information

P.O. Box 62

Oak Ridge, TN 37831-0062

phone: 865.576 .8401

fax: 865.576 .5728

email: mailto:reports@adonis.osti.gov

Available for sale to the public, in paper, from:

U.S. Department of Commerce

National Technical Information Service

5285 Port Royal Road

Springfield, VA 22161

phone: 800.553 .6847

fax: 703.605.6900

email: orders@ntis.fedworld.gov

online ordering: http://www.ntis.gov/ordering.htm 


\section{FAULT ANALYSIS AT A WIND POWER PLANT FOR ONE YEAR OF OBSERVATION}

\author{
Eduard Muljadi \\ National Renewable Energy Laboratory \\ Golden, Colorado \\ eduard_muljadi@nrel.gov \\ Zach Mills and Robert Foster \\ New Mexico State University \\ Las Cruces, New Mexico \\ zmills@nmsu.edu rfoster@nmsu.edu
}

\author{
Jose Conto \\ ERCOT \\ Taylor, Texas \\ jconto@ercot.com
}

\author{
Abraham Ellis \\ Public Service Company of New Mexico \\ Albuquerque, New Mexico \\ aellis@pnm.com
}

\begin{abstract}
The growth of wind energy has mushroomed over the past decade. Over the next twenty years, there will be more significant growth in wind energy with the expectation of $20 \%$ wind grid penetration by 2030 . To accommodate this amount of wind power into our grid, the infrastructure of the transmission grid must be improved. In the high penetration scenario, the ability of wind power plants to stay connected during disturbances is important to avoid a cascading effect due to lack of generation. So-called voltage ride-through capability has become a key criterion for wind integration.

This paper analyzes the fault characteristics observed at a wind power plant, and the behavior of the wind power plant under fault events. The focus of observation is a wind power plant monitored in the Electric Reliability Council of Texas (ERCOT) control area [1]. The wind power plant is monitored during fault events for a period of one year. The fault events are actual faults occurring naturally in the surrounding wind power plants.
\end{abstract}

Index Terms-- wind turbine, wind farm, wind integration, wind power plant, stability, wind energy, aggregation, power system, variable-speed generation, renewable energy, low voltage ride-through, fault analysis

\section{INTRODUCTION}

I $\mathrm{n}$ the next twenty years, there will be more significant growth in wind energy with the expectation of $20 \%$ wind grid penetration by 2030. To accommodate this amount of wind power into our grid, the ability of a wind power plant to stay connected during disturbances is important to avoid cascading disturbances due to lack of generation [2]. Although operational characteristic of the wind power plant is an important aspect of wind power plant [3], the so-called voltage ride-through capability has become a key criterion for wind integration studies. FERC Order 661A requires that wind power plants stay connected during a fault, with the voltage at the point of interconnection (POI) dropping to zero for the duration of nine cycles (150 milliseconds).

The data collected at a Texas wind power plant for a period of one year will be the basis for this analysis. The fault events are actual faults occurring naturally in the surrounding wind power plant. The three-phase voltages and currents were recorded during abnormal values (triggered by events). Thus, the behavior of the wind power plant is recorded during fault events, including pre-faults and post-fault events. Dynamic transients are considered to be a very important aspect of wind power plant contribution to the power grid, and many dynamic models are developed with international collaboration [4]. In the U.S., both ERCOT and WECC are strong supporters in

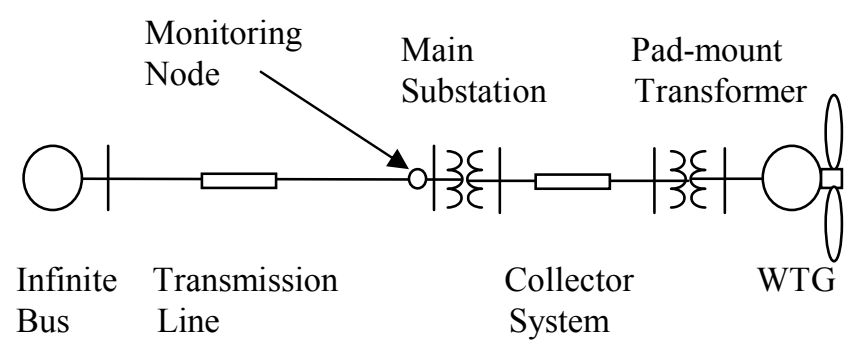

Figure 1. A typical network topology of a large wind power plant.

developing dynamic models of wind turbines and wind power plants [5-6].

A typical wind power plant can be illustrated by the singleline diagram shown in Figure 1 . The wind power plant consists of the equivalent generator, equivalent pad-mount transformer, equivalent collector system, substation transformer, transmission line, and the rest of the grid (infinite bus). The monitoring equipment is placed at the point of interconnection (i.e., the high side of the substation transformer).

In section II, the data monitored and method of analysis are presented. The actual data analysis is presented in section III. Finally, conclusions are summarized in Section IV.

\section{DATA MONITORED}

Data monitored include three-phase currents and threephase voltage. Two types of data are collected: the operational data and the transient data. The operational data is collected at $1-\mathrm{Hz}$ sampling rates and the transient data is collected at high speed of $7760 \mathrm{~Hz}$ sampling rates. The transient data is collected only during transient events (i.e., event triggered) when there is a sudden change of voltage due to transient events. A window event consisting of several seconds of data is recorded and stored permanently. The data is then stored and accessible through a web link protected by a username and password.

In this paper, only the transient data will be used for the analysis. The voltages and currents recorded went through several types of analysis. An example of the recorded data can be seen in Figure 2a. The instantaneous voltage captured during transients show momentary dips. The corresponding currents are shown in Figure 2b, showing a significant increase of the current, indicating that the wind power plant contributes to the fault current.

From the instantaneous data, the rms values of the voltages and current can be computed. From the voltage traces, the 
duration of the fault and the voltage dip is shown. From the current traces, the current conditions are seen before, during, and after transients.

From the voltage wave form in Figure 2, the severity and duration of the fault is described. From the current waveform, the level of power production before and after the fault is evident, as well as the impact of the fault on power production.

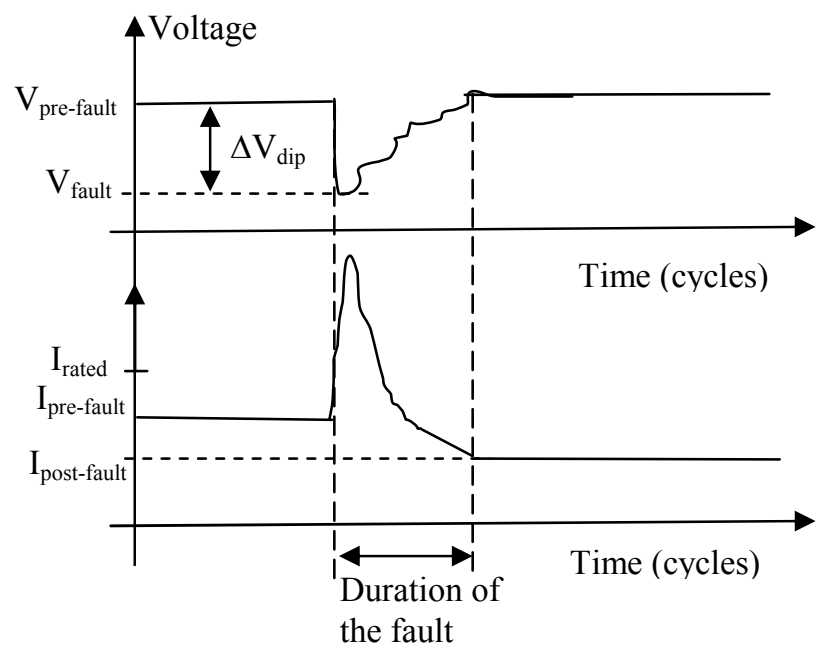

Figure 2. Illustration of voltage and current waveforms during a fault event.

The variables that can be used to measure the fault condition are defined as follows:

$\Delta \mathrm{V}_{\text {dip }}=$ the highest voltage drop during the fault event.

$\Delta \mathrm{t}_{\text {fault }}=$ the duration of the fault event.

$\mathrm{V}_{\text {fault }}=$ the lowest voltage during the fault event.

$\mathrm{V}_{\text {pre_fault }}=$ the pre fault voltage $(1.0 \pm 0.05)$ p.u.

$\mathrm{I}_{\text {rated }}=$ the rated current of the wind power plant.

$I_{\text {pre_fault }}=$ the pre fault current.

$\mathrm{I}_{\text {post fault }}=$ the post fault current.

In general, acceptable voltage variation during normal operation is within $\pm 5 \%$ of nominal voltage. For simplicity of general calculations, it is assumed that normal operating voltage is $100 \%$ or 1.0 p.u. Also, in general, the output of wind power plants is compensated such that the power factor at the point of interconnection is about 1.0 per unit. The output power of the wind power plant varies with wind speed. For low winds, the output power is low, and during high winds, the output power of the wind power plant is at rated capacity (1.0 per unit). With the voltage assumed to be at its per unit value, under a normal situation, the output current of the wind power plant is thus an indication of the output of the wind power plant (i.e., the output current is proportional to the output power of the wind power plant).

During normal operation in a wind power plant, all wind turbines produce the same output level in steady state conditions. The duration of the fault is usually less than nine cycles $\left(\mathrm{t}_{\text {fault }}<150 \mathrm{~ms}\right.$ ), before the circuit breaker clears the fault by removing the faulted lines from the rest of the power system. Within the fault duration it can be assumed that the wind speed does not change. The power production does not change either, unless the fault triggered the relay protection disconnecting some of the turbines due to voltage, current, or frequency as the turbines exceed their allowable range.

With the assumptions presented above, we can characterize the wind power plant behavior under faults. For example, we monitored the data from the wind power plant for a year, and this data is used to characterize the wind power plant during the period of observation (e.g., a year or several years).

In this analysis, it is assumed that all turbines are in working condition and produce power when the wind speed reaches above the cut-in wind speed (assumes no turbine is off-line for repair). The level of power production before the fault event can be determined by finding the ratio of the prefault output current to the rated output current. This number indicates the level of wind speed. For high wind speeds, this number is equal or close to $100 \%$.

$$
\% \text { Power_at_prefault }=\mathrm{I}_{\text {pre_fault }} / \mathrm{I}_{\text {rated }}
$$

The level of power production can be established after the fault event by finding the ratio of the post-fault output current to the rated output current.

$$
\% \text { Power_at_postfault }=\mathrm{I}_{\text {post_fault }} / \mathrm{I}_{\text {rated }}
$$

If no turbine is disconnected during this short time of observation (fault duration), this number is the same as the pre-fault power production. On the other hand, the post-fault power production will be less than the pre-fault power production if there are some turbines disconnected from the grid.

The number of turbines that stay connected during the fault event can be determined by finding the ratio of post-fault power production to the pre-fault power production.

$\%$ Turbines_stays_online $=$

$\%$ Power_at_postfault $/ \%$ Power_at_prefault

Or, it is the same as the post-fault output current to the prefault rated output current.

$\%$ Turbines_stays_online $=\mathrm{I}_{\text {post_fault }} / \mathrm{I}_{\text {pre_fault }}$

In this particular analysis, the following criteria are used for sorting out the number of fault events for the most and least favorable categories.

The most favorable event $=$

If the power production is less than $10 \% P_{\text {rated }}$ and the number of turbines disconnected is less than $20 \%$ of the total number of the turbines. 
The least favorable event $=$

If the power production is more than $80 \% \mathrm{P}_{\text {rated }}$ and the number of turbines disconnected is more than $80 \%$ of the total turbines.

\section{DATA ANALYSIS}

Data collected over a year period are analyzed and presented in this paper. Note that there are many factors impacting the operation and survival of a wind power plant when subjected to fault events, and some of them are listed below:

- The location of the fault with respect to the location of the wind power plant.

- The severity of fault and the type of fault (single line to ground, line-to-line to ground, line to line, threephase to ground).

- The setting of the relay protection.

- The type of wind turbine generator (WTG) used in the wind power plant.

- The control algorithms implemented in the wind power plant (for example, type 3 and type 4 wind turbines are able to operate under voltage control, power factor control, and reactive power control).

- The power system network characteristics (stiff or weak grid).

- The electrical distance of the generator from the load center (i.e., close to the load or far away connected via long radial lines).

- The method of reactive power compensation at the turbine level as well as the power plant level.

\section{A. Typical fault characteristics}

The rms values of the voltages and currents are calculated from the instantaneous data, allowing for determination of the wind power plant operation before and after the fault. Figure 3 shows an illustration of the voltage and the current behavior measured at the point of interconnection during the fault event.

From the voltage traces, the duration of the fault and the voltage dip can be quantified. As shown here, the voltage drops about $14 \%$ for 6 cycles due to the fault occurring somewhere along the transmission line. The voltage drop with respect to the nominal value indicates the distance of the fault from the wind power plant. The relay protection at each turbine is usually set at the same set values. However, due to diversity within the wind power plant, the voltage for each wind turbine will have some differences. When the fault occurs at some point within the transmission line, the voltage presented at the wind power plant, i.e., at individual turbines, may be different. The relay protection at different turbines sense the voltage at different levels and some of the turbines may be triggered to disconnect from the power grid, while others may experience a voltage that is higher than its trigger level. It shown in Figure 3, that all wind turbines within the wind power plant are still connected to the grid.

Figure 4 shows trace currents measured at the POI for different wind power plants at a different location than the one

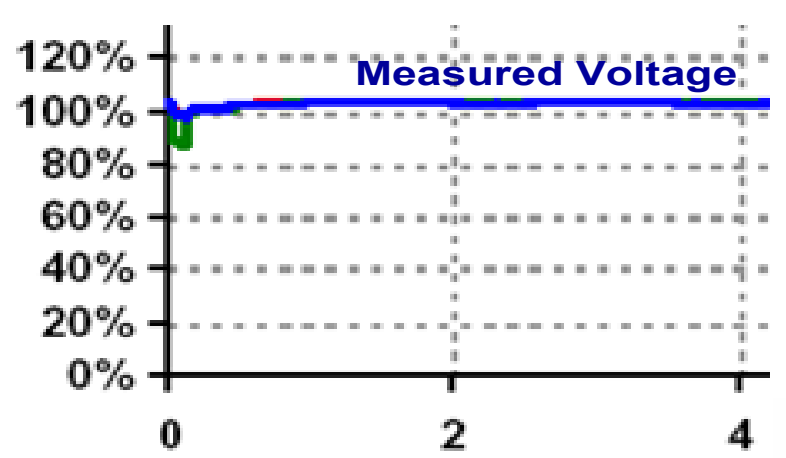

Time (seconds)

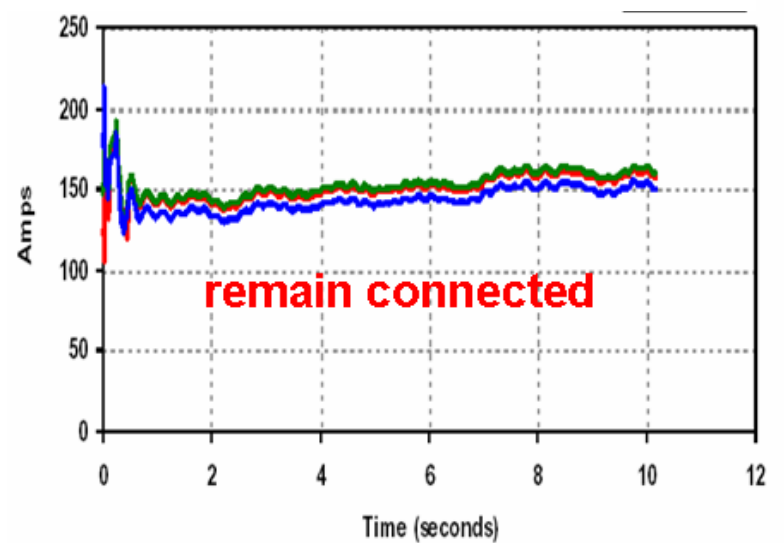

Figure 3: Measurements at the point of interconnection during the fault event. a) Voltage traces b) Current traces.
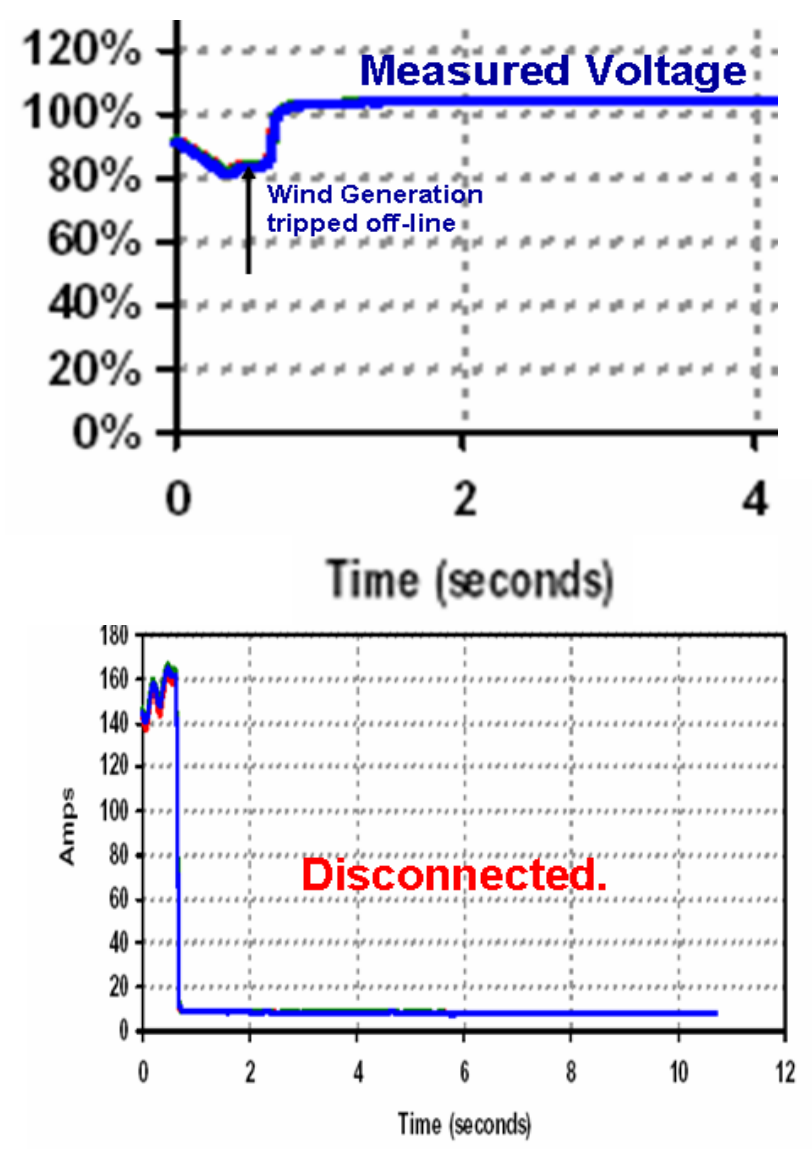

Figure 4: Measurements at the point of interconnection during the fault event. a) Voltage traces b) Current traces. 
shown in Figure 3. In Figure 4, the fault event drops the voltage by $19 \%$ for 38 cycles, and the majority of the wind turbines within this wind power plant are disconnected from the power grid. The larger voltage drop at the POI and the longer duration of the fault may be the cause of the disconnection of the majority of wind turbines within the power plant.

Note that the wind power plant shown in Figure 3 consists of type 1 (squirrel cage directly connected to the grid) wind turbines. Both wind power plants were not designed to have the low voltage ride-through (LVRT) capability.

\section{B. Wind Power Plant in Year 2005}

In this section, a wind power plant is used as the subject of analysis. The first graph, as shown in Figure 5 is voltage at the POI plotted against the duration of the faults. In general, the longer the fault is left un-cleared and the lower the voltage at the POI during the fault, the higher the probability that the wind power plant will stay connected to the power grid. Figures 6 and 7 probe the data in more detail.

\section{1) Fault Characteristics}

Figure 6 shows the bar chart of the fault classification measured at the POI (based on voltage magnitude) of this wind power plant during 2005. It is shown that the majority of the faults occur far away from the wind power plant. Only $27 \%$ of

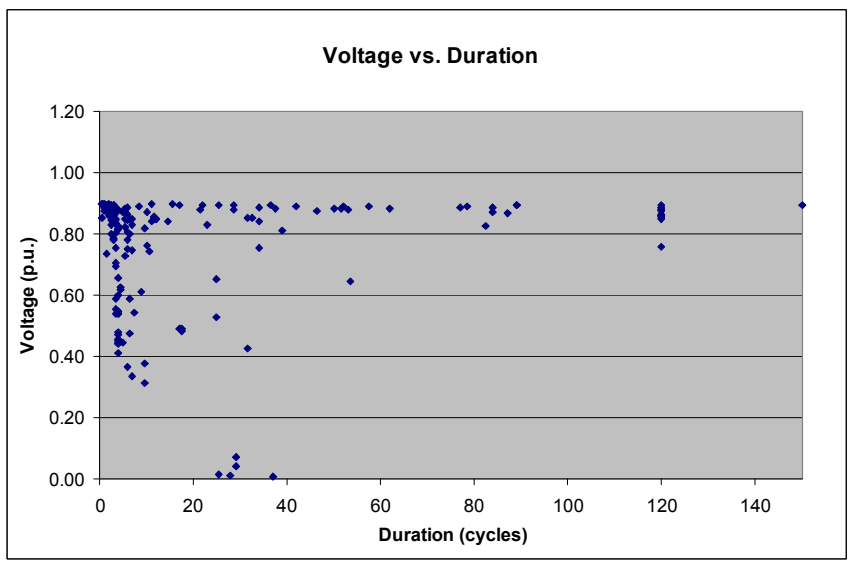

Figure 5. Voltage at the POI versus duration of the fault.

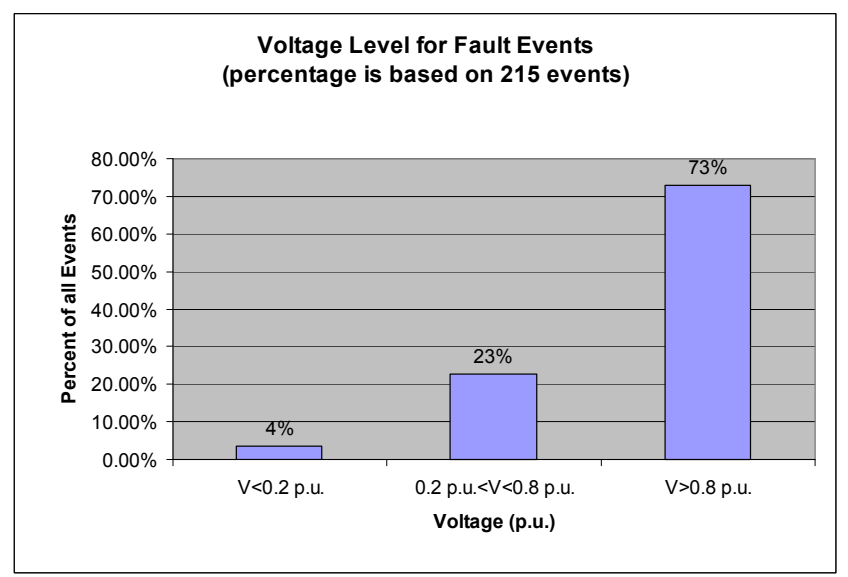

Figure 6. Voltage at the POI during the fault.

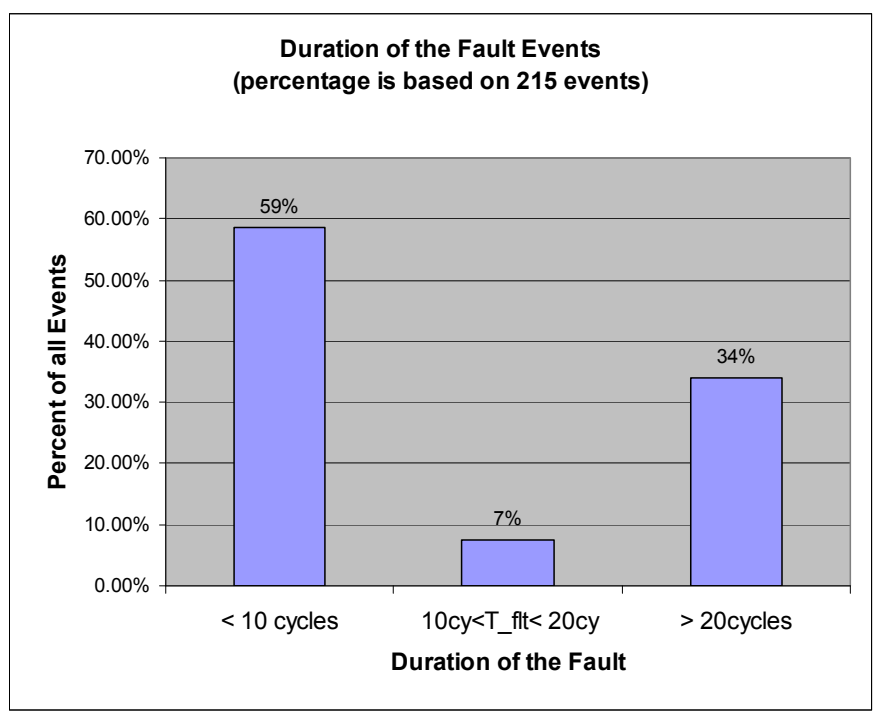

Figure 7. Duration of the fault.

all events cause the POI voltage to drop below 0.8 p.u., thus, the majority of the faults are far-fault events.

Figure 7, shows the bar chart of the fault classification measured at the POI, based on the duration of the fault. It is shown that the majority of the faults occur far away from the wind power plant. It shows that the majority or $59 \%$ of the fault events are cleared in less than 10 cycles, and only $34 \%$ of the faults are cleared by more than 20 cycles. This fault clearing time is not dependent on the wind power plant, but it is set by the relay protection engineers on the circuit breakers installed within the area of the wind power plant.

\section{2) Wind Turbine Characteristics during Faults}

Note that the information presented in Figures 5 through 7 is related to the fault characteristics only. It is not related to the level of production of the wind power plant, nor is it related to the number of turbines dropped due to the fault event. Figure 8 shows the level of power production during the fault events. This figure shows that there is no correlation between the faults and the level of power production (i.e., the grid is stiff enough to transmit power regardless of the level of power production). This information is important because during power generation, it is desirable that the wind power plant help support the power system generation to maintain high reliability. For a high wind penetration scenario, if the wind power plant is removed from the generation pool during the slightest fault event, it may induce the cascading effect commonly associated with a pre-blackout event.

In Figure 8, only $27 \%$ of the fault events occur when the wind turbine produces high power $\left(\mathrm{P}_{\text {gen }}>0.8 \mathrm{P}_{\text {rated }}\right)$. The rest of fault events (73\%) occur during low power production.

Another angle for looking into fault event-related operation is by assessing the survivability of the wind power plant. As described in section II, the number of turbines disconnected from the power grid can be gauged by finding the ratio of the output current during post-fault and pre-fault conditions to the rated current. Thus, the percentage of the turbines disconnected from the wind power plant can be established. 


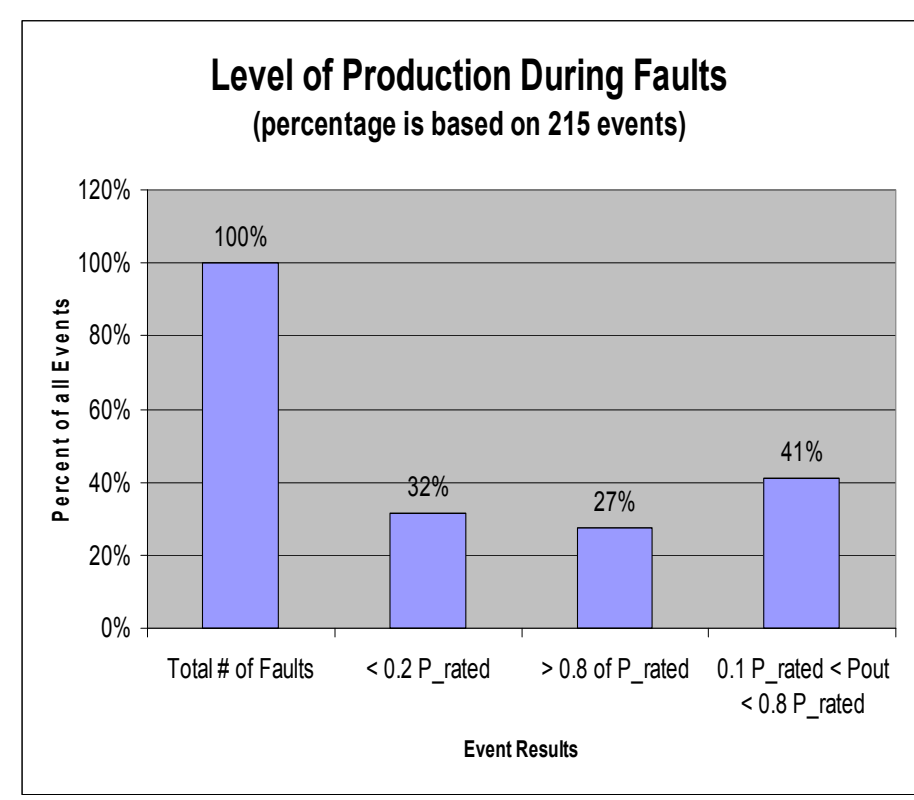

Figure 8 . Wind power plant output at the pre-fault condition.

Figure 9 illustrates the number of turbines that stay connected when there is a fault event. It turns out that $88 \%$ of the time, less than $20 \%$ of the total turbines were disconnected from the grid, while only $5 \%$ of the time did the wind power plant lose $80 \%$ of the total turbines. However, this number does not mean anything to the loss of power generation. Loosing $80 \%$ of existing turbines in a wind power plant does not create any significant threats to the power system stability if this event occurs during low wind (low output power).

Figure 10 illustrates the most favorable events (15\%) and the least favorable events $(1 \%)$. The most favorable events are those which cause the least number of turbines to disconnect from the wind power plant, and the wind speed for that particular event was low. The most favorable events can be translated into the least amount of loss of generated power.

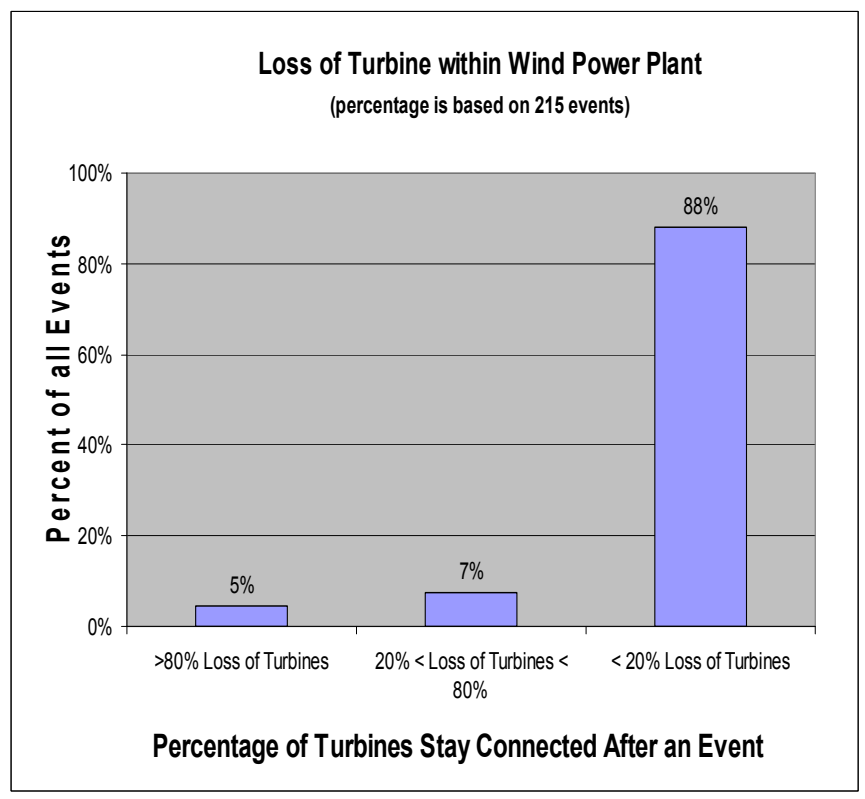

Figure 9. Percentage of turbines that stay on line.

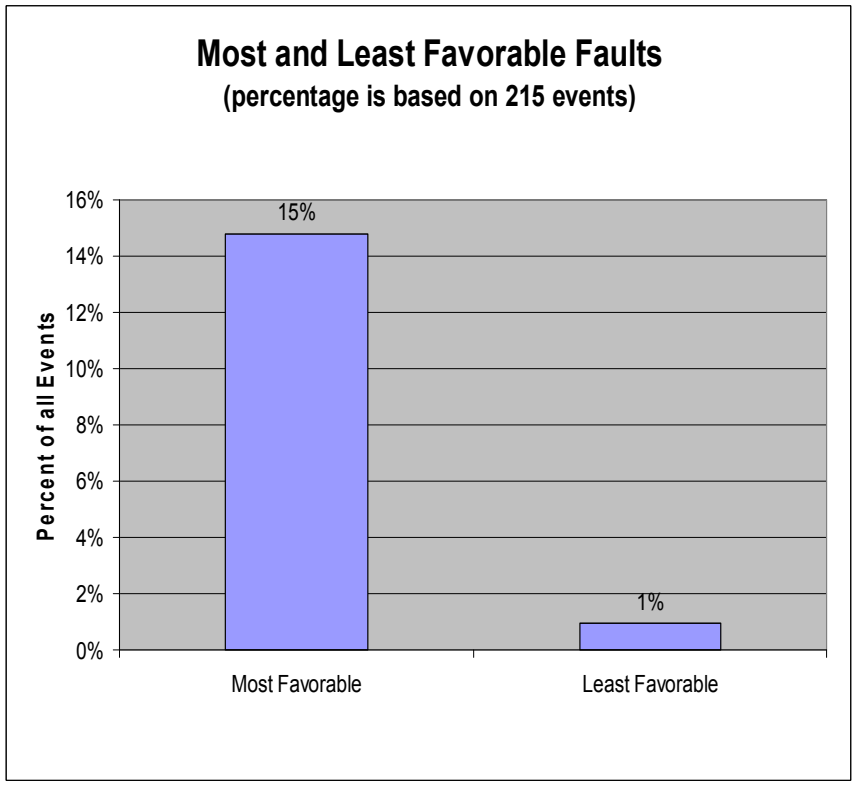

Figure 10. Illustration of the loss of generation during faults.

The least favorable events are those which cause the highest number of turbines to disconnect when the wind speed is high. The least favorable events can be translated into the highest loss of generated power.

\section{3) Seasonal Variations}

Figure 11, shows the seasonal variation effect on the number of fault events. From this graph, the number of events are almost equal during summer (52\%) and winter (48\%). The slightly higher number of events associated with summer in this particular year at this wind power plant can probably be attributed to the faults created by increased vegetation growth that touch the lines.

Next, comparing the events that occur when the output of the wind power plant is higher than $80 \%$ of rated power, it can

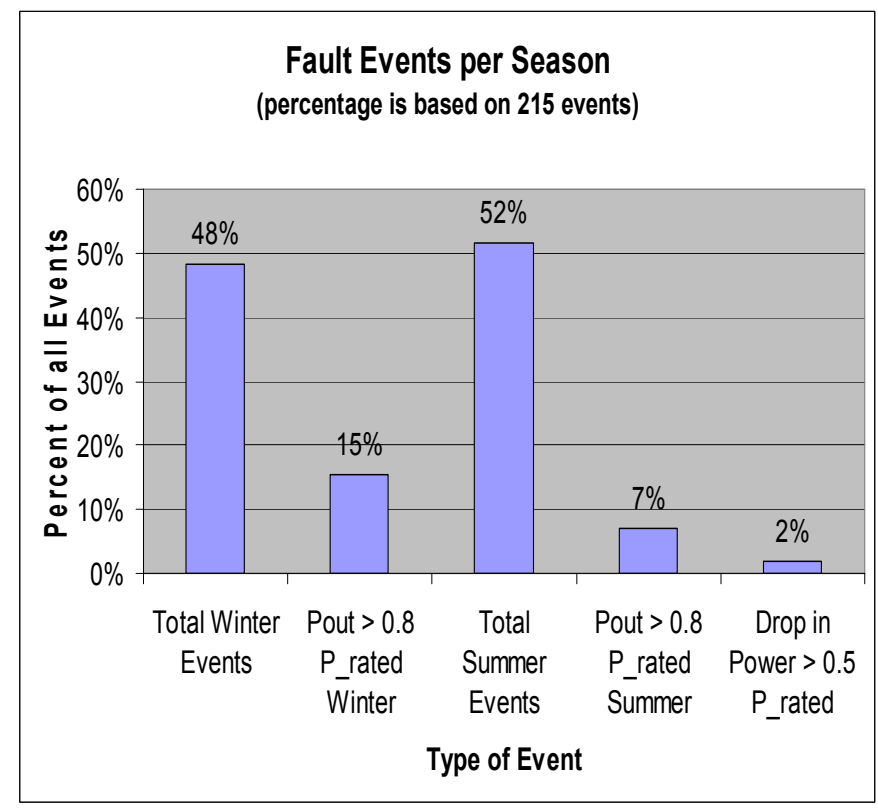

Figure 11. Seasonal variations 
be shown that although the number of fault events are almost the same, the higher incidence of fault events during high power generation in winter ( $15 \%$ versus $7 \%)$ is only an indication that the average wind speed is higher in winter than in the summer.

Finally, let's look into the drop of the power production due to the fault events $\left(\mathrm{P}_{\text {prefault }}-\mathrm{P}_{\text {postfault }}\right) / \mathrm{P}_{\text {rated }}$. In Figure 11, it is shown that for only $2 \%$ of all events, there is a drop of $50 \% \mathrm{P}_{\text {rated }}$. Now, we can also add (from Figure 10 ) that for only $1 \%$ of all events, the wind power plant experienced a drop of $80 \% \mathrm{P}_{\text {rated }}$.

\section{CONCLUSIONS}

From this analysis, it is shown that most of the wind power plant faults are cleared in less than 10 cycles. The fault events mostly occur far from the wind power plant. The loss of generation during fault varies from 0 to $100 \%$ rated power. In terms of loss of generation, the benefit of wind power generation with respect to a conventional synchronous generator is the size of output power disconnected from the plant. For a conventional generator plant, the loss of one single generator can also mean the loss of the rated power for the entire plant. On the other hand, the loss of a single generator in a wind power plant may only equate to the loss of less than $1 \%$ of the total generation. This benefit is clearly displayed in Figure 10 where only 1\% of all the faults of the wind power plant caused high power generation losses $\left(\mathrm{P}_{\text {gen }}>\right.$ $\left.0.8 \mathrm{P}_{\text {rated }}\right)$.

In this paper, fault analysis for a wind power plant was conducted using one year of data collection during 2005. The analysis was conducted using old data, not reflecting current operating condition. The present wind power plant has been improved significantly. If the same analysis is conducted today, it is expected that we can arrive at an even more optimistic conclusion.

\section{ACKNOWLEDGEMENT}

This paper presents part of a project called WECC Wind Generator Modeling. We acknowledge the support of the U.S. Department of Energy, the Western Electric Coordinating Council, and the project funding provided by the California Energy Commission's PIER Program.

The data used in this project is based on data monitored at a wind power plant within the Electric Reliability Council of Texas control area, and funded under an ERCOT-NREL monitoring collaboration.

Zach Mills is a New Mexico State University student supported by National Science Foundation Partnerships for Innovation Program and NREL funding. This work was based on Zach's data analysis during his 2007 internship at NREL.

\section{REFERENCES}

[1] Smith, J. W. (2002). DOE/NREL Wind Farm Monitoring: Annual Report, July 2000-July 2001. 36 pp.; NREL Report No. SR-500-31188.

[2] IEEE Task Force Report "Blackout Experiences and Lessons, Best Practices for System Dynamic Performance, and the Role of New
Technologies", Final Report, May, 2007, Prepared by the Task Force on Blackout Experience, Mitigation, and Role of New Technologies, of the Power System Dynamic Performance Committee, of the Power Engineering Society, of the Institute of Electrical and Electronic Engineering (IEEE), 2007

[3] Wan, Y. H. (2004). Wind Power Plant Behaviors: Analyses of LongTerm Wind Power Data. 66 pp.; NREL Report No. CP-500-36551.

[4] John Olav G Tande, Eduard Muljadi, Ola Carlson, Jan Pierik, Ana Estanqueiro, Poul Sørensen, Mark O’Malley, Alan Mullane, Olimpo Anaya-Lara, Bettina Lemstrom," Dynamic models of wind farms for power system studies-status by IEA Wind R\&D Annex 21," European Wind Energy Conference \& Exhibition (EWEC), London, U.K., November 22-25, 2004.

[5] E. Muljadi, C.P. Butterfield, J. Conto, K. Donohoo, "Ride-Through Capability Predictions for Wind Power Plants in the ERCOT Network" presented at the IEEE Power Engineering Society Annual Conference, San Francisco, CA, June 13-16, 2005

[6] M. Behnke, et al "Development and Validation of WECC Variable Speed Wind Turbine Dynamic Models for Grid Integration Studies" presented at the WINDPOWER 2007 Conference \& Exhibition, Los Angeles, CA, June 24-28, 2007.

\section{BIOGRAPHIES}

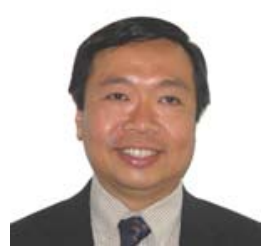

Eduard Muljadi received his Ph. D. (in Electrical Engineering) from the University of Wisconsin, Madison. From 1988 to 1992, he taught at California State University, Fresno, CA. In June 1992, he joined the National Renewable Energy Laboratory in Golden, Colorado. His current research interests are in the fields of electric machines, power electronics, and power systems in general with emphasis on renewable energy applications. He is member of Eta Kappa Nu, Sigma Xi and a Senior Member of IEEE. He is involved in the activities of the IEEE Industry Application Society (IAS), Power Electronics Society, and Power Engineering Society (PES). He is currently a member of Industrial Drives Committee, Electric Machines Committee, and Industrial Power Converter Committee of the IAS, and a member of Working Group on Renewable Technologies and Dynamic Performance Wind Generation Task Force of the PES. He holds two patents in power conversion for renewable energy.

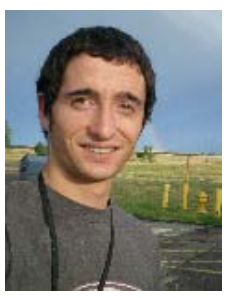

Zach Mills is currently a senior in mechanical engineering at New Mexico State University. He is expecting to graduate with a B.S. in December 2008 He has been working with Robert Foster for the past year and a half under a National Science Foundation Partnerships for Innovation grant. His work includes feasibility assessments for Borderland wind farms for NASA and Ft. Bliss.; during the summer of 2007, he worked at NREL as a student intern, performing the analysis of power system data from several wind power plants. $\mathrm{He}$ is a member of Society of Automotive Engineer, Pi Tau Sigma, and is currently the President of NMSU Chapter of Tau Beta Pi.

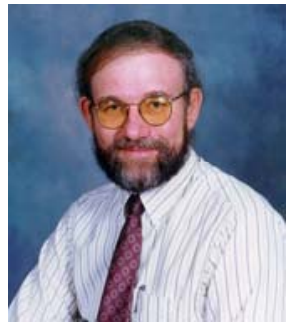

Robert Foster has worked for 19 years at the College of Engineering at New Mexico State University and is the Wind Energy Program Manager for the Institute for Energy and Environment. He has worked with NASA, United Nations, USAID, DOE, USTDA, DOD, NREL, Sandia Labs, and various State and overseas governments on wind energy projects in Brazil, Chile, Dominican Republic, Honduras, and U.S. $\mathrm{He}$ is the NMSU Faculty Leader for the binational NSF Partnerships for Innovation Program promoting wind energy development along the U.S.-Mexico Border. Mr. Foster is a Mechanical Engineering graduate from the University of Texas at Austin, and also holds a MBA from NMSU. He enjoys using wind power with his sailboat Antares. 


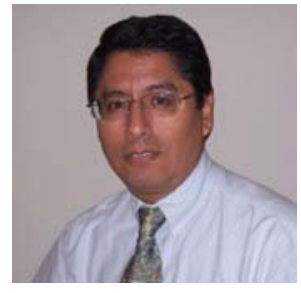

José Conto received his BSEE from the University of Engineers, Lima, Peru in 1981 and his MSEE from University of Tokyo, Tokyo, Japan in 1985. He stayed with CRIEPI, in Japan for one year.

Mr. Conto worked for Electric Research \& Management (State College, PA) on several electrical engineering projects including photovoltaic systems, EMF, solar storm monitoring system, and for the Tokyo Electric Power in Washington DC on utility-scale technology applications before joining the System Planning Department at the Electric Reliability Council of Texas in July 2000. At ERCOT as a Lead Planning Analyst, Mr. Conto performs power system dynamic studies, including voltage and transient stability studies. Past duties included steady state engineering studies, generation interconnection studies, etc. Mr. Conto is an IEEE member. He is fluent in English, Spanish and Japanese.

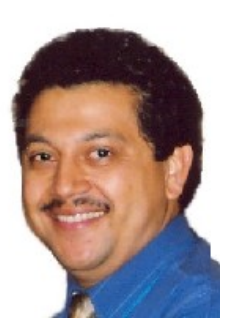

Abraham Ellis graduated from New Mexico State University in 2000 with a Ph.D. in Electrical Engineering. In 2001, he joined the Transmission Operations Department at Public Service Company of New Mexico, where he works in the areas of large generator interconnection studies, transmission expansion planning and special projects related to transmission system performance and monitoring. Abraham is involved with various activities related to wind energy at the regional and national level.

He currently coordinates Western Electricity Coordinating Council's Wind Generator Modeling Group and the IEEE Wind Generator Dynamic Performance Task Force. He also served as Chairman of the Modeling and Validation Work Group until July 2007. Abraham is a Senior Member of IEEE and is a registered Professional Engineer in the State of New Mexico. 


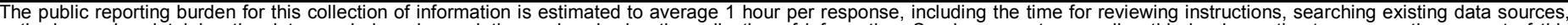

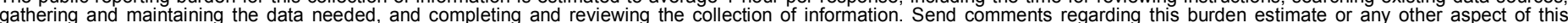

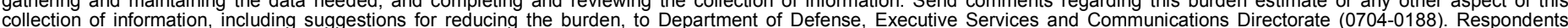

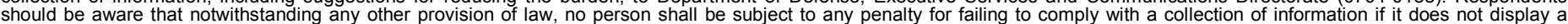

should be aware that notwithstanding

PLEASE DO NOT RETURN YOUR FORM TO THE ABOVE ORGANIZATION.

\begin{tabular}{l|l|l|l} 
1. REPORT DATE $(D D-M M-Y Y Y Y)$ & 2. & REPORT TYPE & 3. DATES COVERED (FrOm - TO)
\end{tabular}

July 2008

Conference Paper

4. TITLE AND SUBTITLE

Fault Analysis at a Wind Power Plant for One Year of Observation:

Preprint

5a. CONTRACT NUMBER

DE-AC36-99-G010337

5b. GRANT NUMBER

5c. PROGRAM ELEMENT NUMBER

6. AUTHOR(S)

E. Muljadi, Z. Mills, R. Foster, J. Conto, and A. Ellis

5d. PROJECT NUMBER

NREL/CP-500-42885

5e. TASK NUMBER

WW1K1000

5f. WORK UNIT NUMBER
7. PERFORMING ORGANIZATION NAME(S) AND ADDRESS(ES)

National Renewable Energy Laboratory

1617 Cole Blvd.

Golden, CO 80401-3393
8. PERFORMING ORGANIZATION REPORT NUMBER

NREL/CP-500-42885

9. SPONSORING/MONITORING AGENCY NAME(S) AND ADDRESS(ES)

10. SPONSOR/MONITOR'S ACRONYM(S) NREL

11. SPONSORING/MONITORING AGENCY REPORT NUMBER

12. DISTRIBUTION AVAILABILITY STATEMENT

National Technical Information Service

U.S. Department of Commerce

5285 Port Royal Road

Springfield, VA 22161

13. SUPPLEMENTARY NOTES

14. ABSTRACT (Maximum 200 Words)

This paper analyzes the fault characteristics observed at a wind power plant, and the behavior of the wind power plant under fault events.

\section{SUBJECT TERMS}

wind turbine; wind farm; wind integration; wind power plant; stability; wind energy; aggregation; power system; variable-speed generation; renewable energy; low voltage ride-through; fault analysis

\begin{tabular}{|c|c|c|}
\hline 16. SECURITY & CLASSIFICATI & N OF: \\
\hline $\begin{array}{l}\text { a. REPORT } \\
\text { Unclassified }\end{array}$ & $\begin{array}{l}\text { b. ABSTRACT } \\
\text { Unclassified }\end{array}$ & $\begin{array}{l}\text { c. THIS PAGE } \\
\text { Unclassified }\end{array}$ \\
\hline
\end{tabular}

\begin{tabular}{|c|c|}
\hline $\begin{array}{l}\text { 17. LIMITATION } \\
\text { OF ABSTRACT }\end{array}$ & $\begin{array}{ll}\text { 18. } & \text { NUMBER } \\
\text { OF PAGES }\end{array}$ \\
\hline UL & \\
\hline
\end{tabular}

19a. NAME OF RESPONSIBLE PERSON

19b. TELEPHONE NUMBER (Include area code) 